\title{
BLOOD ASCORBIC ACID LEVEL IN BIOFLAVONOID AND ASCORBIC ACID THERAPY OF COMMON COLD
}

\author{
Warren L. Franz, M.D., G. Winthrop Sands, M.D. \\ and \\ Henry L. Heyl, M.D., Hanover, N. H.
}

During the past year treatment with the bioflavonoids has been widely publicized as a means of preventing or modifying the common cold. One of the reasons given for the effect has been that they potentiated ascorbic acid (vitamin C) in alleviating cold symptoms. Since there was no convincing proof available, either in support or in denial, we undertook a pilot study to explore the validity of these statements. Within the limits of this study, the bioflavonoid tested showed effect neither on the incidence or cure of colds nor on the ascorbic acid content of the blood. In the course of the study, interesting data Ivere developed regarding the relationship of blood ascorbic acid levels to the incidence and cure of colds. These are reported in detail.

\section{Method}

The study was made on 89 volunteer medical students and student nurses for the three-month period from February to May, 1956. Four groups were established and given capsules (three times daily,

From the Dartmouth Medical School and the Hitchcock Foundation.
- The incidence and course of common colds were followed in 89 medical students and nurses who volunteered in a study of the efficacy of naringin, a bioflavonoid extracted from grapefruit peel and used in remedies for colds. One group of 22 subjects received $333 \mathrm{mg}$. of naringin and $65 \mathrm{mg}$. of ascorbic acid three times daily for three months; a second group received naringin only, another ascorbic acid only, and the fourth a placebo. These substances were administered in capsules as nearly alike as possible. Symptoms of colds were systematically recorded, and the levels of ascorbic acid in the blood were determined periodically. The average level of ascorbic acid in 22 men who were to receive ascorbic acid by mouth was initially $0.96 \mathrm{mg}$. per 100 cc. of blood; after 12 weeks of taking only ascorbic acid the average for this group was $1.41 \mathrm{mg}$. per $700 \mathrm{cc}$. of blood. In all groups and at all stages, the blood ascorbic acid levels for males were significantly lower than those for females. There was no evidence that the naringin affected the ascorbic acid leve/ of the blood, prevented colds, or cured them. 
orally) made up as follows: group L bland placebo: group 2, naringin (bioflavonoid/, $333 \mathrm{mg}$.. and ascorbic acid. $65 \mathrm{mg}$.; group 3, ascorbic acid. $65 \mathrm{mg} .:$ and group 4, naringin (bioflavonoid ), 333 ing. (Naringin is an extract of grapefruit peel.) Every effort was made to disguise the contents of the capsules. All looked

TABLE 1._Blood Ascorbic Acid Level Determinations in Group 1: Patients Given Placebo

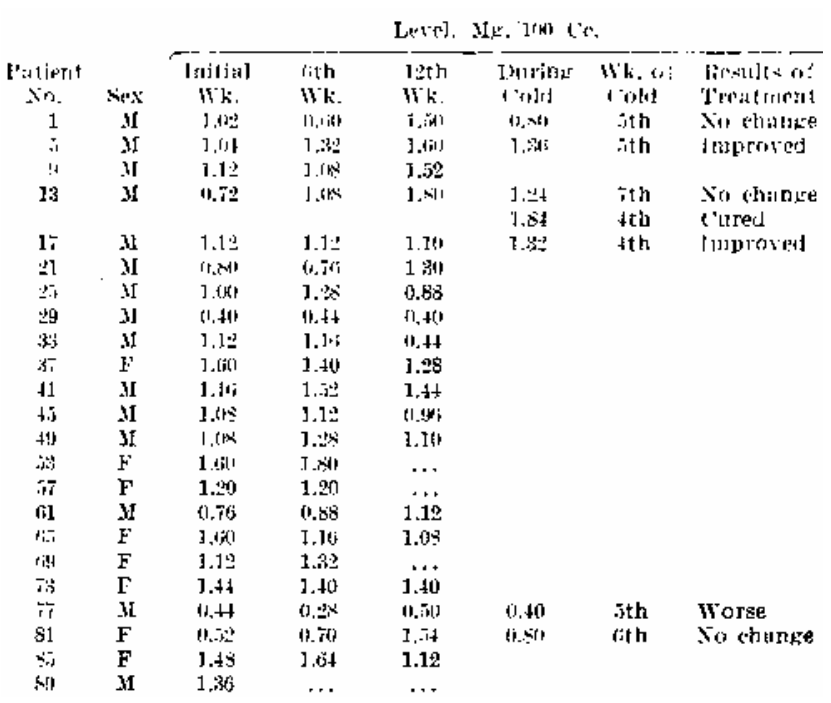

and tasted alike. Even the doctors conducting the study did not know the key to the code numbers used. Groups were assigned in rotation. Thus the first volunteer in line received bland placebo, the second naringin (bioflavonoid) and ascorbic acid, and the fifth bland placebo, as the rotation started over again.

TABLE 2.-Blood Ascorbic Acid Level Determinations in Group 2: Patients Given Bioflavonoid and Ascorbic Acid

\begin{tabular}{|c|c|c|c|c|c|c|c|}
\hline & & & & & & \\
\hline $\begin{array}{c}\text { Pytent } \\
\text { So. }\end{array}$ & Sex & $\begin{array}{l}\text { Inftal } \\
\text { yk. } \\
\text { 1.12 }\end{array}$ & $\begin{array}{l}\text { wth } \\
\text { w.k. } \\
1.48\end{array}$ & $\begin{array}{l}10.25 \\
15 k \\
a, 00\end{array}$ & $\begin{array}{l}\text { During } \\
\text { iold }\end{array}$ & 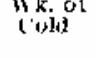 & $\begin{array}{l}\text { Restalls of } \\
\text { Treitmentht }\end{array}$ \\
\hline$\vec{i}$ & XI & 1.08 & 3.12 & 1.4 & $1.0 \mathrm{E}$ & :nd & Cured \\
\hline 20 & MI & 0.80 & 1.16 & 1.28 & $\begin{array}{l}0.5 \mathrm{i} i \\
1.16\end{array}$ & $\begin{array}{l}\text { :nd } \\
\text { lith }\end{array}$ & $\begin{array}{l}\text { l'ured } \\
\text { Worse }\end{array}$ \\
\hline 14 & XI & 0.46 & 1.30 & 1.30 & & & \\
\hline 18 & II & 1.1.2 & $1 .(60$ & 1.85 & $\begin{array}{l}1.12 \\
1.30\end{array}$ & $\begin{array}{l}\text { Isi } \\
\text { ith }\end{array}$ & $\begin{array}{l}\text { Improved } \\
\text { Improved }\end{array}$ \\
\hline 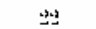 & XI & b.,ikj & $1.5 \%$ & 1.10 & & & \\
\hline$y$ & 31 & (1.): & 1.2 & 1.20 & & & \\
\hline 30 & II & 0.32 & $1 . \overrightarrow{32}$ & $\ldots$ & & & \\
\hline 㩆 & II & $18 . \% 6$ & 1.00 & 1.30 & & & \\
\hline 35 & $r$ & 1.48 & $\therefore .00$ & 1.72 & & & \\
\hline 12 & $\mathrm{u}$ & $1.1 \mathrm{~N}$ & 1.48 & J.30 & 1.600 & t tb & Cured \\
\hline $4(i$ & 3I & 0.49 & $1.0 \mathrm{~s}$ & 1.04 & & & \\
\hline 30 & II & 1.08 & 1.41 & $1 . \tilde{0} 0$ & & & \\
\hline .5t & $\bar{F}$ & 1,40 & J.8. & & & & \\
\hline . & $F$ & $1 . \bar{s} \mathrm{c}$ & 1.84 & 1,98 & & & \\
\hline$\theta_{2}^{2}$ & $\boldsymbol{F}$ & $1 . \mathrm{s}$ & 1.64 & $\ldots$ & & & \\
\hline \{i\}? & $F$ & $1 .+10$ & $1.5 x$ & 1.72 & & & \\
\hline 70 & $\mathbf{F}$ & 1 L & $1.7 t$ & 1.56 & & & \\
\hline it & F & $1 .+8$ & 1.44 & 1.84 & & & \\
\hline Ti & II & 1.82 & $1 .+0$ & 1.84 & & & \\
\hline $8 !$ & II & 0.90 & 1.45 & $\ldots$ & & & \\
\hline$\$ 5$ & $F$ & 1.28 & 1.92 & 1.68 & & & \\
\hline
\end{tabular}

Each subject received a regional physical examination and had blood taken for a determination of ascorbic acid level the day he started the study. All the volunteers were started on the regimen within a single week. Thereafter they continued taking their particular capsule for the three months of the study. At the 6-Aveek and 12-week points in the study, determinations of blood ascorbic acid level were made on all 89 partici- pants. The subject was instructed to report cold symptoms (such as coryza, headache, malaise, fever, or sore throat) the day of onset. At this time the physical examination and determination of blood ascorbic acid level were repeated. He was asked to take no specific cold remedies, not even aspirin or nasal sprays, during the course of the infection. He continued taking the same dosage of the capsule assigned to his group. No antibiotics were used. During the infection the same physician made a record (daily when possible) of the cold's progress or regression. On the fifth day the cold was evaluated as cured, improved, unchanged, or worse.

Two variables were accepted as calculated risks to the accuracy of the study: diet and individual reliability. Although the majority of the subjects ate in the same hospital cafeteria, precise control of their diet was felt to be beyond the scope of this essentially pilot study. We recognized, of course, the varying ele-

\begin{tabular}{|c|c|c|c|c|c|c|c|}
\hline \multirow[b]{2}{*}{$\begin{array}{c}\text { Puticnt } \\
\text { So. }\end{array}$} & \multirow[b]{2}{*}{ x } & \multicolumn{6}{|c|}{ 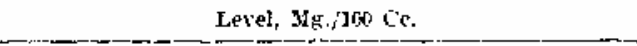 } \\
\hline & & $\begin{array}{l}\text { Initial } \\
\text { Whe. }\end{array}$ & $\begin{array}{l}\text { lith } \\
\text { wik. }\end{array}$ & $\begin{array}{l}1: 3 t h \\
w k .\end{array}$ & $\begin{array}{c}\text { Douring } \\
\text { ['olti }\end{array}$ & $\underset{\text { Wold }}{\text { Whet }}$ & $\begin{array}{l}\text { Results of } \\
\text { Treatmegt }\end{array}$ \\
\hline 3 & .11 & J tis & 1.3. & 1,isil & 1,411 & $3 r a l$ & Inproved \\
\hline$i$ & $3 I$ & 1,3 & 1.82 & $\pm(101)$ & $1\{r ?$ & $3 \mathrm{ral}$ & cured \\
\hline גנ & $M$ & 1.12 & J.36 & $\because(x)$ & $1,3+2$ & $3 \mathrm{rd}$ & cured \\
\hline l.j & 3f & 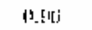 & $1.0 \mathrm{~s}$ & 1.294 & f.sil) & $3 r d$ & Inproved \\
\hline 39 & MI & 1.32 & 1.05 & $(1.8)$ & נ, tS & 3 id & Cured \\
\hline$\because 3$ & $\mathbf{M}$ & 1.14: & $1, \therefore i 2$ & 1.10 & & & \\
\hline ET & $\mathrm{I}$ & 0.82 & 1.28 & 1.40 & & & \\
\hline 31 & $3 \mathrm{I}$ & $1.0 \mathrm{~s}$ & 1.16 & 1.70 & & & \\
\hline 证 & $\mathbf{H I}$ & 18.72 & 6.96 & $\cdots$ & & & \\
\hline $3 ! 1$ & F & 1.96 & $\ldots$ & $\ldots$ & & & \\
\hline 13 & II & 1.12 & 1.18 & 1.20 & & & \\
\hline $4 i$ & M & 4.415 & 1,44 & 1.:n & & & \\
\hline 51. & $F$ & 1.36 & 1.28 & $\ldots$ & & & \\
\hline 政 & $\mathbf{F}$ & 2.64 & trs & 1.32 & & & \\
\hline 50 & $F$ & $1,: 3$ & 1.28 & 1.20 & 1.68 & Ist & Cured \\
\hline $\mathrm{mis}$ & $\mathbf{F}$ & 1.46 & 1, ity & $1 . S t$ & $1 . n^{2}$ & 4th & Cured \\
\hline ti7 & $F$ & 1,28 & 1.72 & $\ldots$ & & & \\
\hline a & $\mathbf{F}$ & 1. 18 & 1.40 & 1.39 & & & \\
\hline 3 & $\mathbf{F}$ & 1.12 & 1.20 & 2.72 & & & \\
\hline 3 & SI & $0.4 \times$ & 1,3; & J.0s & 1, i世 & flh & lmprotesl \\
\hline 83 & 31 & 0. $\{10 ;$ & $\ldots$ & $\ldots$ & & & \\
\hline ล & II & $\left(1,1+\frac{1}{2}\right.$ & $\ldots$ & $\ldots$ & & & \\
\hline
\end{tabular}

grees of reliability with which 89 persons would take 3 capsules a day for three months; we believe, however, that close supervision and the medical orientation of the participants kept this factor of error at a minimum.

Tables 1, 2, 3, and 4 give the detailed blood ascorbic acid levels accumulated during this study. They are included in their complete form, partly because they are the basis for the conclusions of this pilot study and partly because comparable records of blood ascorbic acid levels in normal young adults are relatively rare. (Ascorbic acid blood levels were determined according to the technique of Roe and Kuether ${ }^{1}$ under the supervision of John P. Davison, Ph.D., assistant professor of the physiological sciences in the Dartmouth Medical School.)

\section{Results}

Table 5 summarizes the effectiveness of bioflavonoid with and without ascorbic acid. When used alone, it produced the same results as a placebo. When used with ascorbic acid, the results were comparable to 
those with ascorbic acid alone. Table 6 indicates that the prolonged administration of bioflavonoid had no effect on the blood ascorbic acid level. Females consistently showed a higher blood ascorbic acid level than males (table 6-statistically significant at the 0.01 level). Most of those receiving ascorbic acid showed an increased blood ascorbic acid level. Those receiving ascorbic acid developed just as many colds as those not receiving it (table 5). In this small series, those receiving ascorbic acid showed more rapid improvement in their colds th-in those not receiving it (tables 1 to 5 inclusive-statistically significant at the 0.05 level).

\section{Comment}

Ascorbic acid deficiencies have been noted not only in classic scurvy but in other infectious and metabolic disorders, such as rheumatoid arthritis, rheumatic

TABLE 4.-Blood Ascorbic Acid Level Determinations in Group 4: Patients Given Bioflaconoid

\begin{tabular}{|c|c|c|c|c|c|c|c|}
\hline $\begin{array}{l}\text { Pattiutit } \\
\text { So. }\end{array}$ & $\sec x$ & $\begin{array}{l}\text { Initjul } \\
\text { Wk. }\end{array}$ & $\begin{array}{l}\text { ith } \\
\text { Wk. }\end{array}$ & loth & Ibirisug & Whiof & $\begin{array}{l}\text { liesilts of } \\
\text { 'Ireatiment }\end{array}$ \\
\hline 4 & 31 & $1.2\}_{1}$ & ] & $1 . t t$ & 1.28 & isth & Cusnd \\
\hline 5 & . & $1,0 \mathrm{k}$ & ل8ה, & $1.2 t$ & & & \\
\hline 19 & $\mathbf{3 1}$ & $0 . x^{2} 2$ & 1.20 & 1.20 & & & \\
\hline$l i$ & M & $n+m ;$ & $0.7^{2}$ & $1 .(w)$ & $\begin{array}{l}1.00 \\
0.96\end{array}$ & $\begin{array}{l}\therefore+1 \\
1 \leqslant 1\end{array}$ & $\begin{array}{l}\text { Improved } \\
\text { Worte }\end{array}$ \\
\hline 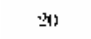 & $M$ & t.1m & $1.0 k$ & 1.011 & & & \\
\hline$\underline{2}_{4}$ & II & 1.t(1) & {$[.(-)]$} & $n, w i_{i}$ & & & \\
\hline 25 & .11 & 1.12 & I.⿻心㇒木 & (b.) & & & \\
\hline $3: 2$ & 31 & 1.조 & $1,+1)$ & $1,(n)$ & & & \\
\hline $31 \mathrm{i}$ & H & $0, x_{0}$ & $1.1 \mathrm{k}$ & $1 . \pm\{1$ & 1. 1411 & נل dוa & Worce \\
\hline Ifis & MI & 1.44 & $10.8 x$ & $1,35)$ & & & \\
\hline$H$ & M & las & $(1,9 \mathrm{lii}$ & 1.7 .3 & 1.115 & $1 \times 1$ & Improperl \\
\hline 19 & M & 1.2h & $0 . \mathrm{f}^{\mathrm{i}} \mathrm{i}$ & 1.20 & & & \\
\hline$w$ & $\mathbf{r}$ & $1.1 \%$ & ] & זئ. & $1,1,2$ & ith & Inprosed \\
\hline ; & F & $1, \overline{s i}$ & 1.tit & $\ldots$ & & & \\
\hline (il) & r & 1.. & ] & $1 .: 27$ & $\begin{array}{l}1.627 \\
1.20\end{array}$ & $\begin{array}{l}3 \times 1 \\
3 \text { th }\end{array}$ & $\begin{array}{l}\text { Improved } \\
\text { Worce }\end{array}$ \\
\hline $1 ; 1$ & $\mathbf{F}$ & J.济 & $1 .+1 t$ & 3.41 & & & \\
\hline dis & $\boldsymbol{r}$ & $1 . N \prime$ & 1.61 & I.|Bi] & & & \\
\hline$i$ & $\mathbf{F}$ & 1.18 & $\ldots$ & $\ldots$ & & & \\
\hline$i t i$ & $\mathbf{F}$ & 1.7 & 1.34 & $\ldots$ & & & \\
\hline : & M & 0.64 & 0.90 & 0.60 & & & \\
\hline$\therefore 1$ & $\mathbf{F}$ & 1.34 & $\ldots$ & $\ldots$ & & & \\
\hline$\therefore x$ & $\mathbf{E}$ & $1, *(j$ & 1.48 & 1,50 & & & \\
\hline
\end{tabular}

fever, tuberculosis, and certain virus infections. The importance of ascorbic acid in maintaining capillary integrity has long been recognized. We will discuss neither the related background nor the literature.

Recently certain naturally occurring substances have been found to have a related function in maintaining the integrity of the intercellular cement substance. The materials as a group have been classified as fluvone glycosides and include such substances as hesperidin, rutin, and naringin. We are particularly concerned with those substances derived from citrus fruit peels, grouped together under the title of bioflavonoids. The significant literature on this subject was summarized at a meeting of the New York Academy of Sciences in 1955, which is reported in the annals of that organization." Various articles in this monograph suggest a relationship between ascorbicacid and the bioflavonoids, with particular reference to their effects on capillary fragility. The monograph also reports the clinical use of the bioflavonoids and ascorbic acid in the treatment of disorders related to decreased capillary permeability. These include polio- myelitis, rheumatic fever, and bleeding related to pregnancy. The hypothesis that the bioflavonoids may prevent or modify colds is apparently based on this same property.

With this possibility in view, a number of drug compounds appeared on the market during the winter of 1955-1956 featuring a bioflavonoid content. Most of these compounds also contained such old cold treatment stand-bys as aspirin, caffeine, and ascorbic acid. The limited statements regarding this treatment of colds reported the use of the whole compound, without reference to specific studies based on the effect of the bioflavonoid alone.

We are reporting a pilot study on the effectiveness of one bioflavonoid per se. It is, of course, not defini-

TABLE 5._-Incidence and Cure of Colds with Bicflavonoid and Ascorbic Acid

\begin{tabular}{|c|c|c|c|}
\hline Gould & $\begin{array}{l}\text { No. in } \\
\text { Gronp }\end{array}$ & $\begin{array}{l}\text { No. Colds } \\
\text { in Groulp }\end{array}$ & $\begin{array}{l}\text { Colde Cirred or } \\
\text { Improsel in } 5 \text { Diass }\end{array}$ \\
\hline Plareilu, & 23 & 7 & $\mathbf{3}$ \\
\hline 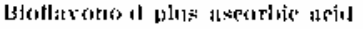 & 292 & ; & 5 \\
\hline Aseribie acli & 쓰 & 8 & $\$$ \\
\hline Bithlaronoitl & 29 & 8 & $t$ \\
\hline
\end{tabular}

tive. But, in the absence of any comparable evaluation of a material whose commercial distribution is already widespread, we feel that even this limited study may be helpful to the medical profession. The approximately 300 determinations of blood ascorbic acid level were a by-product of the bioflavonoid study. The series is far too small to warrant conclusive interpretations, but the data raise several points of interest that may serve as points of departure in more definitive studies. TABLE 6.-Average Blood Ascorbic Acid Level
in Males and Females

Level, $\mathrm{Mg} . / 100 \mathrm{Cc}$.

\begin{tabular}{|c|c|c|c|c|c|c|c|}
\hline \multicolumn{2}{|c|}{ Placebo } & \multicolumn{2}{|c|}{$\begin{array}{c}\text { Bioltaronold } \\
\text { Only }\end{array}$} & \multicolumn{2}{|c|}{$\underset{\text { Anly }}{\text { Ascorble teid }}$} & \multicolumn{2}{|c|}{$\begin{array}{l}\text { Bioflaronaid } \\
\text { and } \\
\text { Aseortife teid }\end{array}$} \\
\hline$M$ & $\boldsymbol{F}$ & $i$ & $\mathbf{F}$ & $\mathbf{3}$ & $\mathbf{F}$ & 31 & $\bar{F}$ \\
\hline 0.0 & 1.8 & 1. & 1. & $0.0 \mathrm{~A}$ & 1,39 & 0. & 1.36 \\
\hline 0,6 & 1.8 & 1.04 & 1. & 1.ßי; & $1 . i s$ & 1. & 1.76 \\
\hline 1.12 & 1.28 & 1.13 & $1 .+33$ & 1.41 & 1.72 & 1.39 & 1. \\
\hline
\end{tabular}

Summary

We are reporting a controlled pilot study of the clinical effect of bioflavonoids and ascorbic acid (vitamin C) on the incidence and cure of the common cold, correlated with serial determinations of blood ascorbic acid level on the 89 medical students and student nurses comprising the test group. The administration of a bioflavonoid had effect neither on the incidence or cure of colds nor on the ascorbic acid level of the blood.

This study was supported by grants from the Nepera Chemical Co., Inc., Yonkers, N. Y., and the Harriet M. Spaulding Charitable Trust.

Statistical analyses were done by J. Laurie Snell, assistant professor of mathematics, Dartmouth College.

All drug preparations were provided by the Nepera Chemical Co., Inc.

\section{References}

1. Roe, J. H., and Kuether, C. A.: Determination of Ascorbic Acid in Whole Blood and Urine Through 2, 4-Dinitrophenylhydrazine Derivative of Dehydroascorbic Acid, J. Biol. Chem. 147:399-407 (Feb.) 1343.

2. Bioflavonoids and the Capillary, edited by R. W. Miner, Ann. New York Acad. Sc. (special issue) 61: July 8, 1955. 